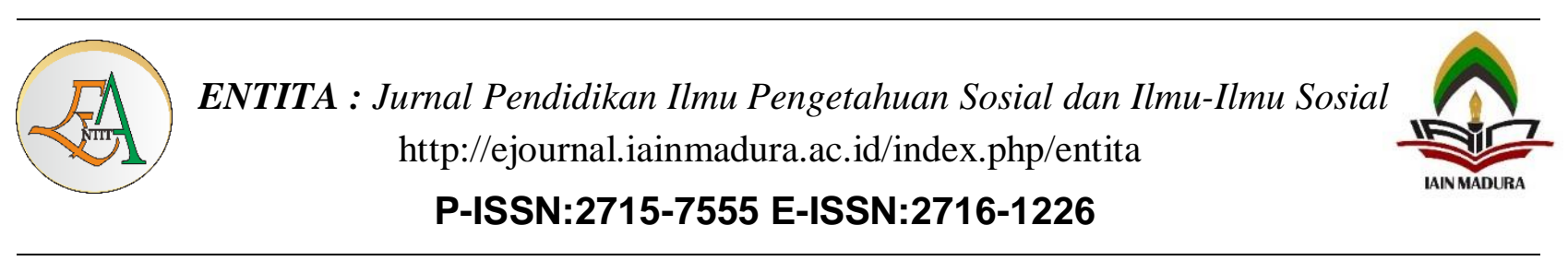

\title{
Pengembangan Bahan Ajar IPS Dinamika Interaksi Sosial di Dalam dan Luar Sekolah bagi Siswa Kelas V MI Mambaul Ulum Tarik Sidoarjo
}

\author{
Inayatu Khoirul Magfiroh \\ IAI ULUWIYAH \\ inayatul@lecturer.uluwiyah.ac.id
}

\begin{abstract}
This research is aimed at developing teaching materials in the form of social studies modules on the dynamics of social interaction inside and outside the Sidoarjo school. The objectives to be achieved are: (1) the preparation of the MI IPS module for class $V$ students in the second semester of MI, (2) the identification of the effectiveness of the MI IPS module on student learning outcomes. This research was carried out through nine stages, namely (1) identifying the general objectives of teaching, (2) carrying out learning analysis, (3) identifying initial input behavior and student characteristics, (4) formulating performance goals, (5) developing test items. benchmark reference, (6) developing teaching strategies, (7) developing and selecting learning materials, (8) designing and implementing formative evaluations, (9) revising learning materials, (9) designing and implementing summative evaluations. Adapted from the Dick and Carey model. The data from the module validation results are obtained as follows: Responses from the validation expert (1) The material quality component on the material suitability criteria has an average score of 2,8 with a good category, on the material shortage criteria has an average score of 3.5 with a good category, while the criteria for learning support materials have an average score of 3.0 with a good category. (2) the linguistic quality component on the criteria for conformity with the level of development of students has an average score of 4.0 with a very good category, on the communicative criteria has an average score of 3.0 with a good category, while the criteria for coherence and integration of the flow of thought has an average score of 3.0 with a good category. (3) the presentation quality component on the presentation technique criteria has an average score of 2,9 with a very good category, while the learning presentation criteria has an average score of 2,9 with a good category. And the criteria for the completeness of the presentation have an average score of 2,9 with a good category. From the results of mastery learning, students using the module get a calculation of the average score for the pre-test is 72, while the average score for the post-test is 80 . Based on the results of data analysis, it can be concluded that the development of teaching materials for the dynamics of social interaction with the resulting product is Modules in Social Studies MI learning obtained module quality and effectiveness to improve mastery learning outcomes, but still require adjustment to the situation and conditions at school.

Keywords: Development of Teaching Materials, Social Interaction, Module

Penelitian ini dalam rangka mengembangkan bahan ajar berupa modul IPS dinamika interaksi sosial di dalam dan diluar sekolah Sidoarjo. Tujuan yang ingin dicapai: (1) tersusunnya modul IPS MI bagi siswa kelas V Semester II MI, (2) teridentifikasinya keefektifan modul IPS MI terhadap hasil belajar siswa. Penelitian ini dilaksanakan melalui sembilan tahap yaitu tahap (1) mengidentifikasi tujuan umum pengajaran, (2) melaksanakan analisis pembelajaran, (3) mengidentifikasi tingkah laku awal masukan dan karakteristik siswa, (4) merumuskan tujuan performasi, (5) mengembangkan butir- butir tes acuan patokan, (6) mengembangkan strategi pengajaran, (7) mengembangkan dan memilih
\end{abstract}


material pembelajaran, (8) mendesain dan melaksanakan evaluasi formatif, (9) merevisi bahan pembelajaran, (9) mendesain dan melaksanakan evaluasi sumatif. Diadaptasi dari model Dick and Carey. Data hasil validasi modul diperoleh sebagai berikut: Tanggapan dari ahli validasi (1) Komponen kualitas materi pada kriteria kesesuaian materi memiliki skor ratarata 2,8 dengan kategori baik, pada kriteria kekurangan materi memiliki skor rata- rata 3,5 dengan kategori baik, sedangkan pada kriteria materi pendukung pembelajaran memiliki skor rata- rata 3,0 dengan kategori baik. (2) komponen kualitas kebahasaan pada kriteria kesesuaian dengan tingkat perkembangan peserta didik memiliki skor rata- rata 4,0 dengan kategori sangat baik, pada kriteria komunikatif memiliki skor rata- rata 3,0 dengan kategori baik, sedangkan pada kriteria keruntutan dan keterpaduan alur pikir memiliki skor rata- rata 3,0 dengan kategori baik. (3) komponen kualitas penyajian pada kriteria teknik penyajian memiliki skor rata- rata 2,9 dengan kategori baik, sedangkan pada kriteria penyajian pembelajaran memiliki skor rata- rata 2,9 dengan kategori baik. Dan pada kriteria kelengkapan penyajian memiliki skor rata- rata 2,9 dengan kategori baik. Dari hasil ketuntasan belajar peserta didik menggunakan modul mendapat perhitungan rata- rata perolehan nilai pre test adalah 72 , sedangkan perolehan rata- rata nilai post test adalah 80 . Berdasarkan hasil analisis data, dapat disimpulkan bahwa pengembangan bahan ajar dinamika interaksi sosial dengan produk yang dihasilkan berupa modul pada pembelajaran IPS MI didapat kualitas modul dan keefektifan untuk meningkatkan ketuntasan hasil belajar, namun masih memerlukan penyesuaian dengan situasi dan kondisi di sekolah.

Kata Kunci: Pengembangan Bahan Ajar, interaksi sosial, Modul

Received : 08 November 2021 ; Revised: 16 November 2021 ; Accepted: 10 December 2021

( ) ENTITA : Jurnal Pendidikan IImu

Pengetahuan Sosial dan IImu-IImuSosial

Institut Agama Islam Negeri Madura, Indonesia

\section{Pendahuluan}

Pendidikan merupakan peristiwa sosial yang berlangsung di dalam latar interaksi sosial. Dikatakan demikian karena Pendidikan tidak bisa dilepaskan dari upaya dan proses saling memengaruhi antara individu yang terlibat didalamnya. Dalam posisi seperti ini, apa yang di namakan Pendidikan dan peserta didik adalah menunjuk pada dua istilah yang dilihat dari kedudukan dalam interaksi sosial. Artinya siapa yang bertanggung jawab atas perilaku, dan siapa yang memiliki peranan penting dalam proses pengubahannya. Karena itu, didalam proses Pendidikan sering kali sukar dikenali siapa yang menjadi pendidik secara permanen karena keduanya dapat mengubah fungsi. (Hamzah B. Uno, 2016:88).

Terkait dengan Pendidikan IPS sendiri, berdasarkan standar kurikulumnya dikatakan bahwa sebagai sebuah bidang studi, IPS mungkin lebih sulit di definisikan secara tepat disbanding dengan mata pelajaran tunggal seperti sejarah atau geografi. Namun disitu digambarkan dua ciri utama yang membedakan IPS dengan ilmu sosial lain yakni (1) IPS didesain untuk mengembangkan kompetensi warga negara, (2) IPS adalah terpadu, yang mengusahakan menggabungkan atau memadukan banyak bidang akademis. (Nasution, 2011:3).

Proses belajar mengajar yang dilakukan oleh pendidik dan peserta didik pada keberlangsungannya saat ini banyak kita temui dengan menggunakan buku teks yang sudah disediakan oleh lembaga pendidikan masing- masing baik itu buku teks untuk guru 
maupun buku teks untuk siswa. Sebagai seorang yang mengerti akan pentingnya kemajuan dan keberhasilan dalam mencapai tujuan pendidikan maka diperlukan adanya sumbangan ide atau bekal pemikiran yang lebih aktif dan kreatif terutama dalam hal proses pembelajaran. Karena pada era sekarang ini khususnya pada kurikulum 2013 disusun dan dirancang dengan tujuan untuk melatih peserta didik dalam berfikir secara ilmiah, dimana peran dari pendidik hanya sebagai fasilitator dalam proses pembelajarannya sedangkan peserta didiklah yang lebih berperan (peran utama) dalam proses pembelajaran.

Adanya pemikiran tersebut maka peneliti mengaitkannya pada pembelajaran IPS pada tingkat SD/ MI yang mana dalam pembelajaran IPS sesuai dengan permendiknas no. 22 tahun 2006, mata pelajaran IPS meliputi bahan kajian Geografi, Sejarah, Sosiologi Dan Ekonomi. Dalam permendiknas ini dijelaskan bahwa mata pelajaran IPS disusun secara sistematis dan terpadu dalam proses pembelajarannya. Dengan proses pembelajaran sistematis dan terpadu, diharapkan pendidikan IPS menjadi lebih bermakna bagi peserta didik dalam konteks kehidupan sehari- hari. Di sini diharapkan peserta didik mendapat gambaran pemahaman yang lebih luas dan utuh (Nasution, 2011: 14).

Lembaga Pendidikan sekolah pada tingkat SD/ MI sudah menerapkan buku tematik sesuai dengan kurikulum 2013 yang mana dalam Bacaan teks ditujukan untuk memberikan stimulus diskusi tentang gambaran interaksi manusia dengan lingkungannya dan keragaman dalam masyarakat. (KD IPS 3.2 yang dipadukan dengan KD PPKn 3.3) dengan memadukan antara pelajaran IPS dengan pelajaran PPKn, siswa di ajarkan untuk mengaitkan antara interaksi sosial dengan kebudayaan yang ada dilingkungan sekitar kehidupan siswa.

Pada kenyataan di lingkungan sekolah masih banyak dijumpai dinamika interaksi sosial Lembaga Pendidikan tidak pernah berada didalam ke hampaan sosial (social vacum) Lembaga Pendidikan memengaruhi dan dpengauhi oleh masyarakat. Apabila Lembaga Pendidikan bergerak secara dinamika maka masyarakat akan berkembang secara dinamik da sebaliknya. Itulah sebabnya ketelitian dalam memhami latar sosial, proses perubahan sosial dan dampak ikutannya akan menentukan keberhasilan Pendidikan, dan begitu pula sebaliknya. (Hamzah B. Uno, 2016: 89)

Oleh karena itu dalam penelitian ini ditujukan pada perubahan interaksi sosial yang terjadi didalam dan diluar sekolah. Yang mana Lembaga sekolah memiliki dampak yang sangat besar terkait dengan interaksi sosial yang dilakukan siswa, dikarenakan para siswa 
lebih banyak menghabiskan waktu mereka di sekolah ketimbang di lingkungan masyarakat.

Selanjutnya dalam penelitian ini nantinya menghasilkan bahan ajar yang berupa modul. Bahan ajar merupakan komponen penting dalam proses pembelajaran. Bahan ajar diperlukan pendidik sebagai pedoman untuk melakukan aktivitas pembelajaran dengan peserta didik. Dengan menggunakan bahan ajar bertujuan untuk memudahkan pendidik dalam mencapai tujuan pembelajaran karena sudah dilaksanakan secara teratur sesuai dengan pedoman materi pada modul pengembangan yang telah dibuat.

Pengembangan pada kondisi interaksi sosial siswa didalam dan diluar sekolah dalam penelitian ini dilakukan pada jenjang Madrasah Ibtidaiyah (MI) yang berada diwilayah Sidoarjo dikhususkan pada kelas V di MI Mambaul Ulum Terik Sidoarjo. Penelitian ini dilaksanakan di jalan KH. Abdul Ghofar, Kenep, Terik, Kec. Krian Kabupaten Sidoarjo, dengan tujuan agar semua peserta didik baik yang bertempat jauh tinggal dekat atau jauh dengan lokasi sekolah dapat memiliki rasa kepekaan sosial dalam menjaga interaksi sosial dengan lingkungannya.

Berdasarkan uraian di atas, masalah penelitian dapat dirumuskan sebagai berikut:

1. Bagaimana kualitas pengembangan bahan ajar IPS dinamika interaksi sosial di dalam dan di luar sekolah bagi siswa kelas V di MI Mambaul Ulum Tarik Sidoarjo?

2. Bagaimana keefektifan pengembangan bahan ajar IPS dinamika interaksi sosial di dalam dan di luar sekolah bagi siswa kelas V di MI Mambaul Ulum Tarik Sidoarjo?

Berbagai penelitian mengenai pengembangan bahan ajar telah banyak dilakukan oleh beberapa peneliti sebelumnya, seperti yang dilakukan oleh Asih dan Hanum (2018) Penelitian ini bertujuan untuk mengetahui bahan ajar tematik integrative berbasis kearifan lokal untuk meningkatkan interaksi social yang layak bagi siswa kelas IV SD. Jenis penelitian ini merupakan penelitian dan pengambangan. Pengembangan mengacu pada model ADDIE (Analyze, Design, Development, Implementation, and Evaluation). Subjek uji coba yaitu expert judgement. Instrumen yang digunakan yaitu lembar penilaian ahli media, ahli materi, ahli pembelajaran dan ahli bahasa. Hasil penelitian ini yaitu bahan ajar yang dikembangkan berupa buku ajar tematik integrative berbasis kearifan lokal untuk meningkatkan interaksi sosial mempunyai tingkat kelayakan sangat baik sebagai bahan ajar pendamping. Berdasarkan penilaian ahli secara keseluruhan baik ahli materi, media, pembelajaran maupun ahli bahasa diperoleh tingkat kelayakan yang sangat baik, serta memiliki tingkat kepraktisan yang baik. Kendala yang dihadapi dalam pengembangan bahan ajar tematik integrative bebasis kearifan lokal yaitu terbatasnya sumber dan 
referensi tentang penulisan bahan ajar yang baik, yang digunakan sebagai acuan penulisan serta keterbatasan refrensi budaya asli kota Yogyakarta.

Berbeda dengan penelitian Asih dan Hanum (2018), pada penelitian Afandi (2012) meneliti tentang: 1) Terdapat hubungan yang signifikan antara interaksi sosial dalam kelompok teman sebaya dengan prestasi belajar mengelola peralatan kantor siswa kelas XI Jurusan Administrasi Perkantoran di SMK Negeri 1 Surakarta Tahun Pelajaran 2012/ 2013; 2) Terdapat hubungan yang signifikan antara motivasi belajar dengan prestasi belajar mengelola peralatan kantor siswa kelas XI Jurusan Administrasi Perkantoran di SMK Negeri 1 Surakarta Tahun Pelajaran 2012/2013; 3) Terdapat hubungan yang signifikan antara interaksi sosial dalam kelompok teman sebaya dan motivasi belajar siswa secara bersama-sama dengan prestasi belajar mengelola peralatan kantor siswa kelas XI Jurusan Administrasi Perkantoran di SMK Negeri 1 Surakarta Tahun Pelajaran 2012/ 2013.

Berbeda dengan penelitian Afandi (2012). Penelitian yang dilakukan oleh Fathimah (2014) Penelitian ini meneliti tentang pengembangan bahan ajar Sejarah pokok bahasan islamisasi berbasis peninggalan Sejarah masjid agung Demak pada siswa kelas XI IPS di SMA Negeri 1 Dempet. Metode penelitian yang digunakan adalah Research and Development $(\mathrm{RnD})$. Sejalan dengan pemikiran Fathimah (2014), pada penelitian Puput (2014) mengenai penelitian tentang penggunaan dan pemanfaatan Teknologi Informasi dan Komunikasi (TIK) pada mata pelajaran akuntansi di SMA Negeri 7 Surakarta. Dalam penelitian ini pengembangan produk bahan ajar akuntansi berbasis TIK memanfaatkan software Wondershare Quiz Creator dan pengembangan bahan ajar akuntansi menerapkan model pembelajaran drill (latihan).

Berbagai penelitian mengenai pengembangan bahan ajar telah banyak dilakukan oleh beberapa peneliti sebelumnya, seperti yang dilakukan oleh I Dewa, dkk (2014) mengkaji pengembangan bahan ajar IPS berorientasi IPS terpadu untuk siswa SMP kelas VII. Penelitian menggunakan model pengembangan Dick and Carey yang telah diadaptasi. Penelitian ini bertujuan untuk mengembangkan bahan ajar IPS Terpadu yang teruji validitas dan efektivitasnya dalam upaya meningkatkan prestasi belajar siswa SMP kelas VII.

Sehingga dari keempat penelitian terdahulu tersebut dapat kita simpulkan bahwa penelitian pengembangan bahan ajar telah banyak dilakukan oleh beberapa peneliti sebelumnya. Pada penelitian ini mengadaptasi penelitian terdahulu yang telah dilakukan 
oleh I Dewa, dkk (2014) yang mengkaji tentang pengembangan bahan ajar IPS berorientasi IPS terpadu untuk siswa SMP kelas VII. Karena pada penelitian ini juga menggunakan model pengembangan Dick and Carey. Karena pada dasarnya alasan penelitian pengembangan bahan ajar yang dikembangkan oleh peneliti memilih desain pengembangan Dick and Carrey yang dirasa sesuai dengan kondisi pembelajaran anak didik di Ml Mambul Ulum Tarik Sidoarjo. Selain itu pada penerapannya sama menggunakan sepuluh langkah dari desain pengembangan Dick and Carrey.

Nama IPS dalam kurikulum 1975 itu merupakan nama mata pelajaran di sekolah yang merujuk pada sosial studies di Amerika berdasarkan hasil kesepakatan para ahli kita dalam seminar nasional tentang civic education tahun 1972 di Tawangmangu, Solo (Sapriya, 2009; 19; Udin S. Winataputra, 2010, 1. 30-1. 31). Bila dibandingkan dengan kurikulum 1968, konsep IPS dalam kurikulum 1975 tercatat empat hal yang penting untuk digaris bawahi yakni (1) pendidikan moral pancasila mendapat penguatan dan pemberiannya dipisah dengan mata pelajaran IPS guna sebagai transmits basic aspect of cultural heritage (transmisi dasar aspek pewarisan budaya); (2) IPS terpadu untuk sekolah dasar.

(3) Ditingkat SMP, IPS merupakan paying dari mata pelajaran Sejarah, Geografi/ Kependudukan, Ekonomi/ Koperasi; (4) IPS diajarkan secara terpisah yang terbagi dalam mata pelajaran mencakup mata pelajaran Pendidikan Moral Pancasila, Sejarah, Geografi/ Kependudukan, Antrpologi- Budaya, Ekonomi/ Koperasi, dan Tata Buku Hitung dagang (Dep. P dan K, 1975; Udin S. Winataputra, 2010: 1. 31) (Nasution, 2011:2).

Sejalan dengan itu dalam Permendiknas no. 22 tahun 2006 menyebutkan bahwa pembelajaran IPS adalah merupakan perpaduan dari berbagai disiplin ilmu sosial seperti Sosiologi, Geografi, Ekonomi, Sejarah. Dari sekian konsep dasar IPS itu, pada dasarnya esensi pendidikan IPS adalah mengembangkan pengetahuan dan keterlibatan dalam masalah- masalah warga Negara seperti masalah pemeliharaan kesehatan, kejahatan, kebijakan luar negeri dan sebagainya adalah bersifat multidisiplin. Oleh karena itu pemahaman masalah ini dan upaya pemecahannya membutuhkan pendidikan multidisiplin. Karakteristik seperti ini adalah kunci pendidikan IPS.

Bahan ajar atau learning material, merupakan materi ajar yang dikemas sebagai bahan untuk disajikan dalam proses pembelajaran. Bahan pembelajaran dalam penyajiannya berupa deskripsi yakni berisi tentang fakta- fakta dan prinsip- prinsip, norma yakni berkaitan dengan aturan, nilai dan sikap, serta seperangkat tindakan/ keterampilan motorik. Bahan pembelajaran pada dasarnya berisi tentang pengetahuan, nilai, sikap, 
tindakan dan keterampilan yang berisi pesan, informasi, dan ilustrasi berupa fakta, konsep, prinsip, dan proses yang terkait dengan pokok bahasan tertentu yang diarahkan untuk mencapai pembelajaran (Konjo, 2011).

Dalam penelitian digunakan bahan ajar berupa dinamika interaksi sosial didalam dan diluar sekolah untuk menyampaikan materi pembelajaran, yang dijelaskan sebagai berikut.

1. Pengertian bahan ajar pada Pendidikan dan masyarakat

Dilihat dari kepentingan masyarakat secara menyeluruh, fungsi utama Pendidikan sebagai alat pemelihara (pengembang) kebudayaan. Kemampuan seseorang untuk belajar, mengorganisir sesuatu dalam bentuk simbolik, mengomunikasikan pengetahuan kepada oang lain, dan perilaku yang dihasilkan dari belajar aaupun bedasarkan pebgetahuan merupakan sumber fenomena kebudayaan. (Hamzan dan nina, 2016:90)

2. Klasifikasi bahan ajar dinamika interaksi sosial didalam dan diluar sekolah

Bahan ajar pada interaksi sosial didalam dan diluar sekolah merupakan salah satu jenis materi pembelajaran mandiri kepada peserta didik karena produk yang dihasilkan berupa modul yang dapat digunakan secara langsung dan secara lengkap dibuat oleh pendidik dari mulai materi sampai pada rangkuman dan soal latihan. Dikhususkan pada kompetensi dasar yang dipilih dan sesuai dengan tujuan pembelajaran.

3. Fungsi bahan ajar interaksi sosial siswa di MI Mambaul ulum

Interaksi sosial yang terjadi pada siswa baik didalam maupun diluar sekolah terjadi Ketika siswa mengalami proses tatap muka antara guru dan siswa ataupun siswa dengan orang tua ataupun juga siswa dengan masyarakat. Diharapkan dengan adanya proses interaksi sosial siswa dapat meng interpretasikan tema pada sub bab mengenai Menganalisis bentuk-bentuk interaksi manusia dengan lingkungan dan pengaruhnya terhadap pembangunan sosial, budaya, dan ekonomi masyarakat Indonesia

4. Manfaat bahan ajar pada interaksi sosial siswa di dalam dan di luar sekolah MI Mambul Ulum

a. Menarik minat peserta didik hingga dapat meningkatkan minat belajar.

b. Memperjelas makna bahan pelajaran sehingga mudah untuk dipahami dan memungkinkan peserta didik dapat menguasai tujuan pembelajaran dengan baik. 
c. Membuat variasi metode mengajar sehingga tidak hanya komunikasi verbal antara pendidik dan peserta didik. Hal ini diharapkan peserta didik tidak akan cepat bosan dengan metode mengajar pendidik.

Dari hasil pemaparan mengenai permasalahan sosial yang timbul dikalangan masyarakat dikaitkan peneliti dengan kondisi sosial atau keadaan sosial masyarakat. Pada penelitian ini kondisi interaksi sosial siswa didalam dan diluar sekolah Ml Mambaul Ulum. Interaksi sosial yang dimaksud dalam penelitian ini adalah (1) antara guru dengan siswa, (2) antara siswa dengan orang teman sebaya, (3) antara siswa dengan orang tua, dan (4) antara siswa dengan masyarakat.

Dalam sejarah masa lampau, terutama pada peradaban Yunani dan romawi, Pendidikan formal hanya dimanfaatkan oleh kalangan terbatas, yakni golongan elit yang berkuasa dan anggota kelompok agama. Dengan adanya revolusi industry, selain menghasilkan inovasi secara radikal juga mengubah struktur sosial masyarakat. Fungsi utama keluarga tidak lagi menjadi unit produksi sebagaimana yang terjadi pada masyarakat petani primitive. Akibatnya, banyak anak muda bekerja di pabrik dan kantor. Perubahan ini juga menyebabkan generasi muda semakin menuntut agar memperoleh peluang lebih banyak dalam dunia Pendidikan.(hamzah dan nina, 2016: 90)

Berkaitan dengan hal itu, sekolah menjadi suatu kebutuhan karena keluarga dan masyarakat menjadi kurang efektif dan kurang mampu dalam melatih anak- anak menjadi dewasa melalui hubungan informal. Kelompok agen kebudayaan guru dan orang awam semakin berkembang. Perubahan jenis- jenis pengetahuan dan pekerjaan menyebabkan anak- anak menjadi dewasa melalui hubungan informal. Kelompok agen kebudayaan guru dan orang awam semakin berkembang. Perubahan jenis- jenis pengetahuan dan pekerjaan menyebabkan anak- anak masuk ke ruang sekolah, dan memberikan peranan yang lebih luas dan lebih dalam untuk melangsungkan dan mentransmisikan kebudayaan.(hamzah dan nina, 2016: 91)

Keluarga juga tidak akan kehilangan kepentingannya dalam mendidik anak- anak Ketika mereka menginjak usia sekolah. Dalam banyak hal orang, orang tua dan saudarasaudaranya terus memengaruhi sosialisasinya selama usia sekolah, begitu pula sampai mereka mencapai usia dewasa. Itu mungkin terjadi masalah khusus bagi sekolah atas pembagian tanggung jawab dibidang sosialisasi tersebut. Sekolah bukan saja mendidik anak anak yang sudah memperoleh seperangkat nilai, melainkan sekolah juga harus menyeleseikan pengaruh parallel dan yang kadang- kadang berkompetisi dari bawaan 
keluarga, atau dari kelompok sebaya, selama anak- anak dalam masa Pendidikan. .(hamzah dan nina, 2016: 91)

Karena anak- anak mengahabiskan waktunya di sekolah, atau kegiatan- kegiatan yang berkaitan dengan sekolah tidaklah mengejutkan bahwa lingkungan pergaulan disekolah akan memengaruhi perilakunya termasuk juga bentuk system nilai dan sikapnya terhadap norma- norma sosial. Karena itu hanya dengan memperluas lingkungan pergaulannya, anak- anak memperoleh peluang untuk mempersiapkan diri secara tepat pada berbagai peran yang harus dilakukan didalam masyarakat dewasa. Untuk berfungsi sebagai orang dewasa, anak harus belajar bukan saja peranan orang tua, melainkan juga peranan siswa, guru, pemimpin kelompok, dan akhirnya sebagai suami ataupun istri.

Fungsi selanjutnya Lembaga Pendidikan ini membantu mengalokasikan seseorang pada posisi didalam masyarakat. Setiap masyarakat selalu membagi tugas dalam memutuskan sesuatu berkenanaan dengan kepentingan Bersama, dan melaksanakan peranan penting bagi kelangsungan dan perkembangan masyarakat.

Kondisi sosial yang diteliti dalam hal ini adalah mengenai interaksi yang terjadi antara siswa dengan guru, interaksi antara siswa dengan siswa, interaksi antara siswa dengan orang tua, dan interaksi antara siswa dengan masyarakat. Dimana interaksi terjadi apabila ada tatap muka anatara kedua belah pihak sehingga menimbulkan komunikasi yang searah. Dari komunikasi tersebut didapat penerimaan yang bersifat positif dan penerimaan yang bersifat negative.

Penelitian ini mengkhususkan pada kondisi sosial yang ada di sekitar lingkungan Madrasah Ibtidaiyah dilingkungan Tarik Sidoarjo dijadikan sebagai bahan ajar pembelajaran IPS kelas $\mathrm{V}$ untuk mata pelajaran IPS, dengan memakai model pengembangan Dick and Carey. Model ini dipilih karena tiga alasan. Pertama, karena pada awal proses pembelajaran anak didik atau peserta didik dapat mengetahui dan mampu melakukan hal- hal yang berkaitan dengan materi pada akhir pengajaran. Kedua, adanya pertautan antara tiap komponen khususnya antara strategi pengajaran dan hasil pengajaran yang dikehendaki. Ketiga, menerapkan langkah- langkah yang perlu dilakukan dalam melakukan perancangan desain pembelajaran. Pada model pengembangan dari Dick and Carey melalui sepuluh langkah dalam penerapannya.

Dari pengembangan model Dick and Carey selanjutnya disusun modul pembelajaran. Modul adalah satu kesatuan program yang lengkap, sehingga dapat dipelajari oleh peserta didik secara individual (Wina, 2008: 155-156). Modul dibuat 
kemudian di validasi oleh tim ahli. Kemudian setelah divalidasi modul disusun sebagai bahan ajar dan digunakan dalam proses pembelajaran dikelas. Dari hasil pembelajaran dengan menggunakan modul kemudian peneliti mengukur dari hasil penerapan modul dikelas V MI Miftahul Ulum Tarik Sidoarjo dapat meningkatkan pemahaman peserta didik pada pelajaran IPS materi Menganalisis bentuk-bentuk interaksi manusia dengan lingkungan dan pengaruhnya terhadap pembangunan sosial, budaya, dan ekonomi masyarakat Indonesia.

\section{Metode}

Pengembangan bahan ajar ini menggunakan adaptasi model pengembangan Dick and Carey. Model ini dipilih karena tiga alasan. Pertama, karena pada awal proses pembelajaran anak didik atau siswa dapat mengetahui dan mampu melakukan hal- hal yang berkaitan dengan materi pada akhir pengajaran. Kedua, adanya pertautan antara tiap komponen khususnya antara strategi pengajaran dan hasil pengajaran yang dikehendaki. Ketiga, menerapkan langkah- langkah yang perlu dilakukan dalam melakukan perancangan desain pembelajaran (Hamzah, 2006:24). Sehingga dari hasil pemaparan alasan peneliti tersebut maka dapat dikaji dengan pengembangan yang difokuskan pada kondisi sosial yang dikembangkan menjadi suatu bentuk bahan ajar untuk para peserta didik setingkat Madrasah Ibtidaiyah (MI). Masalah sosial dalam penelitian ini adalah kondisi interaksi sosial siswa di dalam dan diluar sekolah MI Mambaul Ulum.

Adapun uji coba ini meliputi beberapa langkah yaitu: Rancangan Uji Coba Produk yang dihasilkan berupa modul dan akan diuji validitasnya dengan tahapan sebagai berikut: (a) review oleh team ahli bidang studi, (b) review oleh ahli bahasa, (c) review oleh ahli desain pembelajaran, dan (d) uji coba lapangan. Hal ini dapat diketahui hasilnya dari tanggapan para ahli, siswa, guru berdasarkan saran dan tanggapan dalam angket.

Kelayakan pengembangan bahan ajar yang dibuat mempunyai indikator utama yaitu: (a) pemilihan tema dalam pembelajaran IPS harus sesuai dengan kompetensi inti dan kompetensi dasar pembelajaran, (b) adanya keterpaduan antara tema yang dipilih dengan mata pelajaran IPS yang lain, atau adanya pengintegrasian dengan mata pelajaran IPS dikhususkan pada mata pelajaran (sosiologi). (c) Kelayakan pendisainan pengembangan materi pembelajaran dengan kebutuhan siswa dalam pembelajaran IPS baik kelayakan pada tulisan ataupun gambar, (d) kemenarikan atau kemudahan bahasa yang digunakan di dalam desain produk bahan ajar yang dikembangkan baik secara jelas, 
lugas, komunikatif, alur berpikir yang runtut dari penyajian permasalahan sampai kepada tujuan pembelajaran, adanya kesesuaian penggunaan bahasa Indonesia yang baik dan benar serta dengan kesesuaian pada penggunaan simbol dan istilah.

Desain uji coba merupakan kesatuan langkah kegiatan pengembangan dengan menggunakan model perancangan dan pengembangan pengajaran menurut Dick and Carrey. Uji coba pada pengembangan ini meliputi:

a. Validasi ahli yang dilakukan oleh tim ahli terhadap isi bahan ajar untuk mengatahui kesesuaian isi pengembangan bahan ajar dan kemenarikan desain serta penggunaan bahasa dalam pembuatan modul tersebut.

b. Guru mata pelajaran IPS di MI Mambaul Ulum Tarik Sidoarjo, yang bertujuan untuk mengetahui kesesuaian dan kelayakan modul dari tujuan pembelajaran berdasarkan Kompetensi Inti dan Kompetensi Dasar.

c. Siswa- siswi kelas V MI Mambaul Ulum Tarik Sidoarjo, yang bertujuan untuk menilai kejelasan isi/ bahan ajar yang diambil dari kondisi sosial siswa kelas $\mathrm{V} \mathrm{MI}$, apakah menarik, mudah dipahami, mengarahkan belajar dan memotivasi belajar.

Subjek penelitian ini adalah siswa- siswi kelas V MI Mambaul Ulum Tarik Sidoarjo tahun ajaran 2020-2021, yang berjumlah 31 orang. Jenis penelitian ini bersifat kualitatif dimana data kuantitatif diperoleh dari angket yang disebarkan kepada tim validator, guru mata pelajaran IPS, dan siswa- siswa kelas V MI Mambaul Ulum Tarik Sidoarjo, isi dari angket tersebut nantinya berupa kesimpulan dan saran atas isi dari modul tersebut layak atau tidaknya untuk digunakan dalam pembelajaran.

Modul yang digunakan adalah berupa modul yang diterapkan di kelas bertujuan untuk memperoleh gambaran tentang kegiatan pembelajaran dengan menggunakan modul dari kondisi interaksi sosial siswa kelas V di MI Mambaul Ulum Tarik Sidoarjo. Serta untuk mengetahui aktifitas siswa/ peserta didik ketika berlangsung proses pembelajaran.

Penelitian pengembangan ini melalui beberapa tahapan. Tahapan dari penelitian ini dapat dijelaskan sebagai berikut: 1). Menentukan potensi dan masalah. 2) Mengumpulkan informasi. 3) Desain modul. 4) Validasi modul. 5) Revisi modul. 6) Uji coba modul. 7) Produk akhir.

Terkait dengan penelitian pengembangan bahan ajar dari kondisi interaksi sosial siswa didalam dan di luar sekolah, penelitian ini dilakukan di kelas V MI Miftahul Ulum Tarik Sidoarjo, peneliti menggunakan beberapa cara atau teknik pengumpulan data yang 
akurat dan bertujuan untuk menjawab masalah penelitian yang telah dijabarkan oleh peneliti. Data dalam penelitian ini diperoleh dari:

1. Observasi partisipasi

Merupakan teknik yang dilakukan peneliti dengan cara melibatkan diri langsung kepada obyek penelitian yang dipilih. Hal ini terkait dengan observasi partisipan, peneliti mengamati apa yang dikerjakan oleh guru mata pelajaran IPS kelas $\mathrm{V}$ di MI Miftahul Ulum Tarik Sidoarjo, mendengarkan apa yang dia ucapkan dan menuliskan aktifitas pekerjaan yang dilakukan ketika proses pembelajaran. Pengamatan ini mengamati proses pembelajaran pada produk pengembangan bahan ajar dari kondisi siswa kelas V. Melihat masalah dan kesulitan apa saja yang terjadi, serta melakukan evaluasi disetiap akhir proses pembelajaran.

2. Teknik tes

Teknik tes adalah tes formatif yang berupa serangkaian pertanyaan terkait dengan materi yang disampaikan guru. Format tes formatif diberikan dalam bentuk tes obyektif pilihan ganda dan beberapa tes varian yang dapat meningkatkan daya ingat peserta didik. Tes obyektif diberikan kepada peserta didik karena diharapkan dapat memberikan kemudahan para peserta didik untuk melakukan pengukuran (pemberian nilai) atas kemampuan pribadinya. Tes ini diharapkan menghasilkan nilai peserta didik setelah kegiatan pembelajaran berlangsung.

3. Dokumentasi

Teknik yang dilakukan berupa pencarian data berdasarkan dokumen terdahulu yang berupa jurnal, skripsi, tesis, disertasi, catatan harian, foto, gambar, audio. Studi dokumentasi ini adalah tahapan dalam mengumpulkan informasi dalam pencapaian tujuan penelitian yang mana semua data yang diperoleh dari teknik informasi ini dikumpulkan menjadi satu lalu di olah dan dipilah peneliti agar diperolah kumpulan data yang kongkrit dan dapat mendukung tujuan penelitian yang diharapkan.

Teknik analisis data yang digunakan untuk mengolah data yang dihimpun dari uji coba lapangan yaitu dengan menggunakan analisis penelitian deskriptif, data yang didapat berupa angket. Data tersebut dianalisis dalam bentuk analisis bentuk skor kriterium menggunakan skala likert. Penggunaan skala likert untuk data frekuensi respon siswa terhadap modul pengembangan dari interaksi sosial siswa di dalam dan di luar sekolah, penelitian ini dilakukan di kelas V MI Miftahul Ulum Tarik Sidoarjo setelah dikembangkan. Untuk mendapatkan hasil yang lebih jelas maka menggunakan hasil skala 
perhitungan juga dilakukan dengan persentase (\%). Formula persentase pada masingmasing jawaban subjek dengan menggunakan rumus:

$$
\text { persentase }=\sum \frac{\text { keseluruhan skor jawaban angka } \times 100 \%}{n \times \text { bobot terting } 1 \text { ix jumlah responden }}
$$

keterangan: $\mathrm{n}=$ jumlah seluruh item angket.

Skor yang diperoleh kemudian dikonversikan menjadi nilai dengan skala 4, yaitu membagi nilai standar menjadi empat skala atau empat kualifikasi. Skala 4 dalam teknik statistik penelitian dan pengembangan ini yaitu $A=$ Sangat kurang, angka $B=$ kurang, angka $C$ = baik, angka $D=$ cukup baik. Untuk mengetahui kualitas bahan ajar hasil pengembangan dari aspek materi maupun aspek isi modul, serta untuk mengetahui respon siswa terhadap bahan ajar, maka dari data yang mula- mula berupa skor, diubah menjadi data kualitatif dengan skala empat.

Skor untuk setiap item diperoleh dari jawaban angket yang disebarkan kepada para peserta didik, dengan menggunakan instrument penilaian lima skala tersebut. Instrument penilaian menggunakan skala likert dibuat dalam bentuk checklist atau pilhan ganda (Sugiono: 2008).

\section{Result and Discussion}

Instrument respon peserta didik diberikan kepada peserta didik setelah proses belajar mengajar berlangsung. Sedangkan rekapitulasi respon peserta didik terhadap pembelajaran IPS dengan menggunakan modul materi pengembangan dapat dilihat pada tabel 1 dengan rumus:

$$
\text { Hasil persentase }=\sum \frac{\text { Jumlah jawaban respon peserta didik } x}{\text { jumlah banyaknya peserta didik }}{ }^{-}
$$

Kategori skor nilai peserta didik dikategorikan sebagai berikut, a) sangat baik, b) baik, c) cukup baik, d) kurang baik. Hal ini tertera pada table berikut ini:

Tabel 1

Kategori skor nilai respon peserta didik

\begin{tabular}{cc}
\hline Persentase & Kategori \\
\hline $0 \%-20 \%$ & Tidak baik \\
$21 \%-40 \%$ & Kurang baik \\
$41 \%-60 \%$ & Cukup \\
$61 \%-80 \%$ & Baik \\
$81 \%-100 \%$ & Sangat baik \\
\hline & (Riduwan, 2011: 41)
\end{tabular}




\section{Komponen kualitas materi}

Hasil validasi kualitas materi memiliki skor rata- rata 3,0 dengan kategori baik, hal ini dapat dilihat kelengkapan materi, keluasaan materi dan kedalaman materi sudah memenuhi syarat yang baik yang sesuai dengan ranah kompetensi dasar dan indicator pencapaian yang sesuai dengan kebutuhan peserta didik dalam penulisan modul tentang interaksi sosial siswa di dalam dan diluar sekolah MI Mambaul Ulum Tarik Sidoarjo. Sedangkan pada poin akurasi fakta dan konsep materi cukup akurat dengan penyajian fakta dan konsep yang dapat dimaknai sebenarnya, dan ilustrasi materi memiliki skor 3,0 dengan kategori baik yang sesuai dengan indikator pembelajaran. Pada materi pendukung kesesuaian perkembangan ilmu dan teknologi sudah disajikan sesuai dengan perkembangan peristiwa yang terjadi sekarang. Sedangkan pada contoh gambar dan ilustrasi sudah disajikan secara baik sesuai dengan kenyataan sebenarnya yang terjadi dilapangan dengan memiliki skor rata- rata 3,0 kategori baik.

Table 2

Hasil Analisis Validasi Kualitas Komponen Materi

\begin{tabular}{|c|c|c|c|c|}
\hline No & Kriteria- kriteria & Nilai & Rata- rata & Kategori \\
\hline \multirow[t]{4}{*}{ A } & Kesesuaian Materi & & 2,8 & Baik \\
\hline & 1. Kelengkapan materi & 2,6 & & Baik \\
\hline & 2. Keluasan materi & 2,8 & & Baik \\
\hline & 3. Kedalaman materi & 3,0 & & Baik \\
\hline \multirow[t]{3}{*}{ B } & Kekurangan materi & & 3,5 & Baik \\
\hline & 4. Akurasi fakta dan konsep & 4,0 & & Sangat baik \\
\hline & 5. Akurasi ilustrasi & 3,0 & & Baik \\
\hline \multirow[t]{5}{*}{ C } & Materi Pendukung Pembelajaran & & 3,0 & Baik \\
\hline & $\begin{array}{l}\text { 6. Kesesuaian Perkembangan IImu } \\
\text { dan Teknologi }\end{array}$ & 4,0 & & Sangat baik \\
\hline & $\begin{array}{l}\text { 7. Keterkinian fitur, Contoh, dan } \\
\text { Ilustrasi }\end{array}$ & 3,0 & & Baik \\
\hline & 8. Kontekstual & 2,7 & & Cukup \\
\hline & 9. Salingtemas & 3,0 & & Baik \\
\hline
\end{tabular}

\section{Komponen kualitas kebahasaan}

Komponen kebahasaan modul disesuaikan dengan tingkat kemampuan dan cara peserta didik dalam berfikir pada proses pembelajaran. Hasil validasi menunjukkan pada kesesuaian bahasa dengan tingkat berpikir dan emosional peserta didik memiliki skor rata- rata 3,0 dengan kategori baik. Ini menunjukkan bahwa bahasa yang disampaikan pada materi yang diajarkan runtut sesuai dengan tingkat pola berfikir peserta didik pada tingkat sekolah menengah pertama, yang mana pada kalimat setiap 
paragrafnya disajikan runtut dengan tatabahasa yang komunikatif sesuai dengan tujuan dari materi yang disajikan.

Table 3

Hasil Analisis Validasi Kualitas Komponen Kebahasaan

\begin{tabular}{|c|c|c|c|c|}
\hline 49 & leAnalisis Kritariāasikiteriąias Kompo & $\mathrm{Nilai}$ & asta-ranta & Kategori \\
\hline A & $\begin{array}{l}\text { Kesesuaian dengan tingkat } \\
\text { perkembanqan peserta didik }\end{array}$ & & 4,0 & Sangat baik \\
\hline & $\begin{array}{l}\text { 1. Menurut perkembangan berpikir } \\
\text { tingkat sekolah menengah } \\
\text { pertama }\end{array}$ & 4,0 & & Sangat baik \\
\hline & $\begin{array}{l}\text { 2. Menurut perkembangan } \\
\text { emosional tingkat sekolah } \\
\text { menengah pertama }\end{array}$ & 4,0 & & Sangat baik \\
\hline B & Komunikatif & & 2,7 & Baik \\
\hline & 3. Keterpahaman pesan & 2,6 & & Baik \\
\hline & 4. Ketepatan tata bahasa dan ejaan & 2,7 & & Baik \\
\hline & 5. Kebakuan istilah dan symbol & 2,8 & & Baik \\
\hline C & $\begin{array}{l}\text { Keruntutan dan keterpaduan alur } \\
\text { piker }\end{array}$ & & 3,0 & Baik \\
\hline & $\begin{array}{l}\text { 6. Keruntutan makna dalam materi } \\
\text { ajar }\end{array}$ & 2,9 & & Baik \\
\hline & $\begin{array}{l}\text { 7. Keterpaduan makna dalama } \\
\text { materi ajar }\end{array}$ & 3,0 & & Baik \\
\hline
\end{tabular}

\section{Komponen Kualitas Penyajian}

Hasil validasi kualitas penyajian mencakup urutan konsep, sistematika yang konsisten, dan kesinambungan antar BAB dengan memiliki skor 3,6 dengan kategori sangat baik. Hal ini menunjukkan bahwa dari konsep yang telah sesuai dengan tujuan pembelajaran yang diinginkan dari sistematika sampai dengan isi antar BAB runtut dari mulai dari penyebab sampai dengan dampak yang ditimbulkan.

\section{Table 4}

Hasil Analisis Validasi Kualitas Komponen Penyajian

\begin{tabular}{clccc}
\hline No & \multicolumn{1}{c}{ Kriteria- kriteria } & Nilai & Rata- rata & Kategori \\
& & & & \\
\hline A & Teknik Penyajian & 2,9 & & Sangat baik \\
& 1. Keurutan konsep & & Sangat baik \\
& $\begin{array}{l}\text { 2. Kekonsitenan sistematika } \\
\text { 3. Kesinambungan antar BAB }\end{array}$ & 3,0 & & Baik \\
B $\begin{array}{l}\text { Penyajian pembelajaran } \\
\text { 4. Berpusat pada kebutuhan peserta }\end{array}$ & 3,0 & & baik \\
& didik & & Baik \\
5. Mengembangkan keterampilan & 2,9 & & Baik \\
\hline
\end{tabular}




\begin{tabular}{|c|c|c|c|c|}
\hline \multirow{6}{*}{ C } & $\begin{array}{l}\text { peserta didik } \\
\text { 6. Memperhatikan keselamatan } \\
\text { kerja peserta didik }\end{array}$ & 3,0 & & baik \\
\hline & 7. Variasi penyajian & 2,8 & & Baik \\
\hline & Kelengkapan Penyajian & & 2,9 & Baik \\
\hline & 8. Pendahuluan & 3,0 & & Baik \\
\hline & 9. Isi & 2,9 & & Sangat baik \\
\hline & 10. Penutup & 3,0 & & Baik \\
\hline
\end{tabular}

No

Uraian Pernyataan

Persentase rata- rata respon peserta

didik

Tertarik\% $\quad$ Tidak Tertarik\%

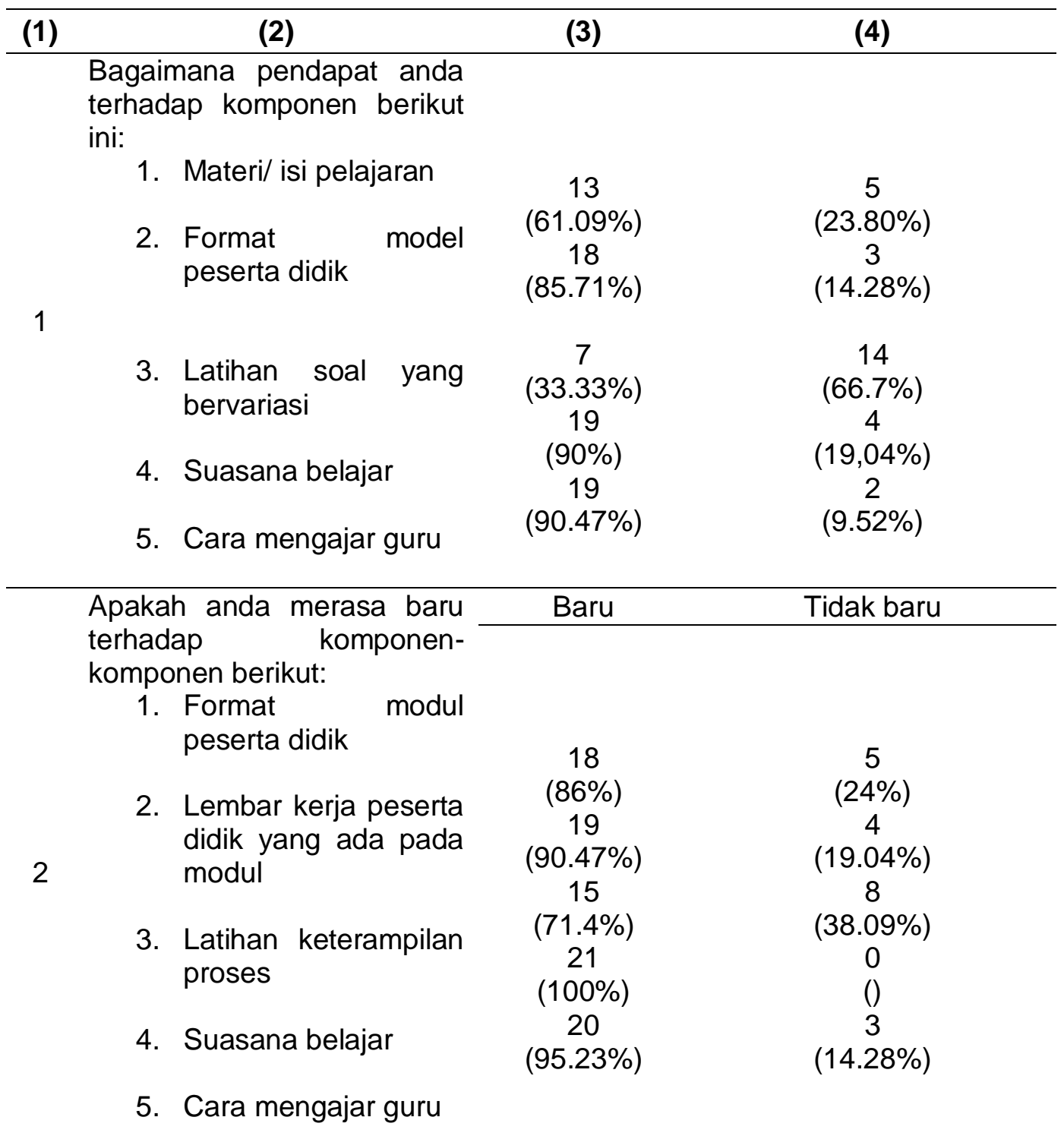

3 Apakah anda dengan mudah Mudah Sulit 
memahami komponen-

komponen berikut:

1. Bahasa di dalam modul peserta didik

2. Materi ajar/ isi modul peserta didik

3. Contoh- contoh soal

4. Lembar kerja peserta didik

5. Cara mengajar guru

$\begin{array}{cc}6 & 17 \\ (28 \%) & (81 \%) \\ 5 & 18 \\ (24 \%) & (86 \%) \\ 5 & 14 \\ (24 \%) & (66,7 \%) \\ 16 & 3 \\ (76,19 \%) & (14.28 \%) \\ 20 & 3 \\ (95.23 \%) & (14.28 \%) \\ & \end{array}$

17

$(81 \%$

$(86 \%)$

$66,7 \%)$

$(14.28 \%$

$14.28 \%$

\begin{tabular}{|c|c|c|c|}
\hline \multirow[b]{2}{*}{4.} & \multirow{2}{*}{$\begin{array}{l}\text { Bagaimana penjelasan guru } \\
\text { pada saat kegiatan belajar } \\
\text { mengajar? }\end{array}$} & Mudah (\%) & Sulit (\%) \\
\hline & & $\begin{array}{c}15 \\
(71.42 \%) \\
\end{array}$ & $\begin{array}{c}6 \\
(28.57 \%) \\
\end{array}$ \\
\hline \multirow[b]{2}{*}{5.} & \multirow{2}{*}{$\begin{array}{l}\text { Bagaimanakah bimbingan } \\
\text { guru pada saat mengerjakan } \\
\text { lembar kegiatan peserta } \\
\text { didik selama kegiatan belajar } \\
\text { mengajar berlangsung? }\end{array}$} & Minat (\%) & Tidak berminat (\%) \\
\hline & & $\begin{array}{c}16 \\
(76.19 \%)\end{array}$ & $\begin{array}{c}6 \\
(28.57 \%)\end{array}$ \\
\hline 6. & $\begin{array}{l}\text { Bagaimanakah minat kalian } \\
\text { untuk mengikuti } \\
\text { pembelajaran dengan } \\
\text { menggunakan modul pada } \\
\text { kegiatan belajar mengajar } \\
\text { yang berlangsung? }\end{array}$ & Minat (\%) & Tidak berminat (\%) \\
\hline
\end{tabular}

\section{Respon Peserta Didik}

Instrument respon peserta didik diberikan kepada peserta didik setelah proses belajar mengajar berlangsung. Sedangkan rekapitulasi respon peserta didik. secara umum peserta didik tertarik atau senang terhadap pembelajaran yang dilakukan dengan menggunakan modul tersebut. Hal ini ditunjukkan dengan persentase rata- rata ketertarikan peserta didik terhadap materi pembelajaran, format modul peserta didik, lembar kerja peserta didik, latihan soal yang bervariasi, suasana belajar dan cara mengajar guru masing- masing dengan skor 90.47\%, 95.23\%, 76.19\%, 71.42\%, $76.19 \%$.

Tabel 5

Kendala-kendala yang ditemui saat melaksanakan KBM KENDALA SOLUSI

1. Pembelajaran dengan menggunakan modul relative baru bagi para peserta didik di MI
1. Pada pembelajaran yang baru diajarkan oleh peneliti di sekolah tersebut dengan cara pembelajaran yang aktif dan 


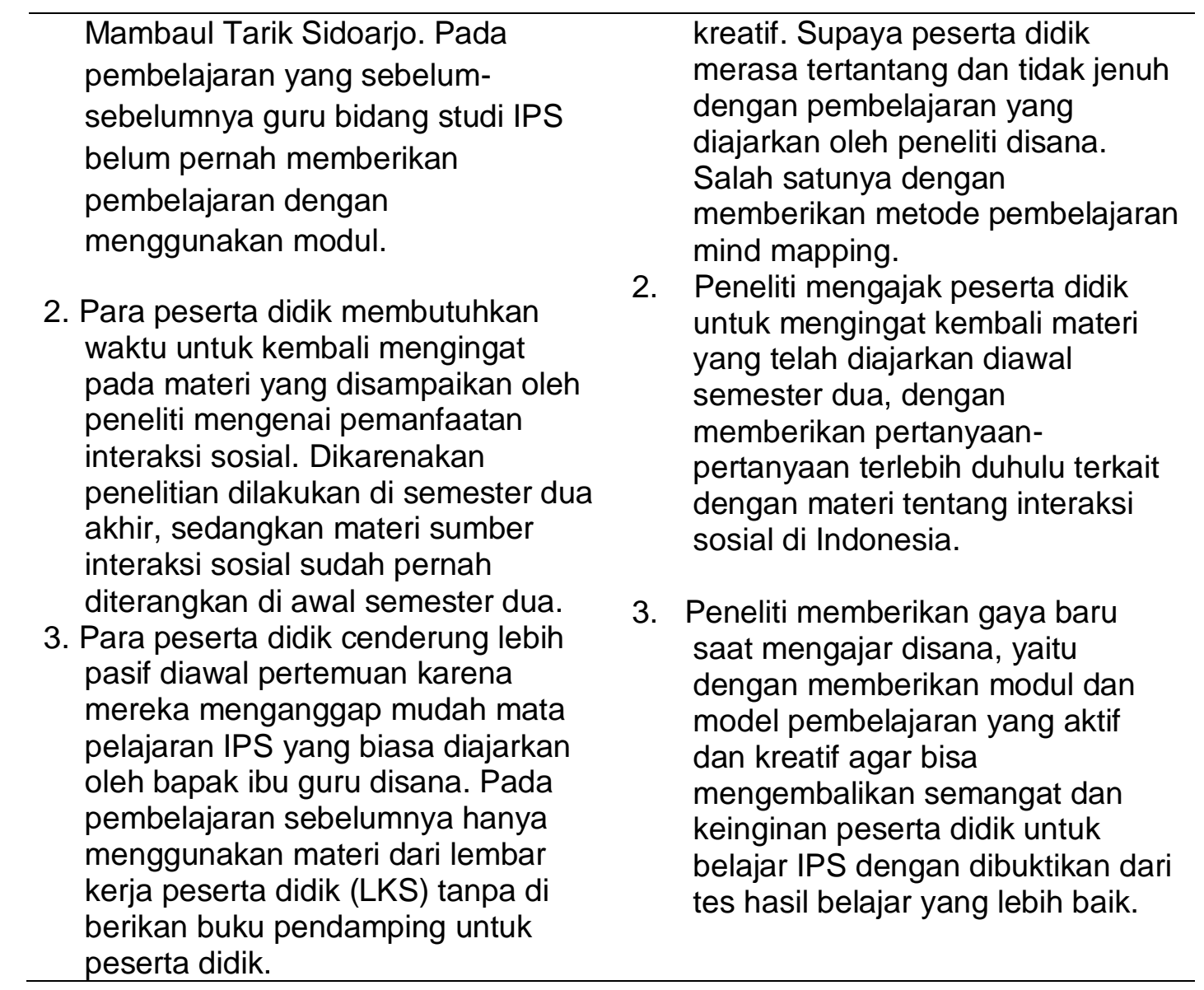

\section{Kesimpulan}

Pengembangan bahan ajar IPS MI menghasilkan modul yang sudah teruji dan layak untuk digunakan sesuai dengan komponen kualitas materi, komponen kualitas kebahasaan, dan komponen kualitas penyajian. Modul berisi tentang interaksi sosial di dalam dan di luar sekolah. Modul telah diuji kualitas dan keefektifannya pada validator ahli dan dapat diterapkan pada proses pembelajaran IPS dikelas V MI Mambaul Ulum Tarik Sidoarjo. Sehingga dapat dikatakan sudah memenuhi kualitas dan keefektifan penggunaan modul.

\section{Referensi}

Aprihastanto, Afandi. (2012). Hubungan Antara Interaksi Sosial Dalam Kelompok Teman Sebaya Dan Motivasi Belajar Dengan Prestasi Belajar file://D:/tugas\%20JURNAL/jurnal\%20interaksi\%20sosial/garuda1419376.pdf. Diakses tanggal 28 September 2021.

Fathimah Zahra. (2014). Pengembangan bahan ajar Sejarah pokok bahasan Islamisasi berbasis peninggalan Sejarah masjid agung Demak. (Online), 
journal.unnes.ac.id/sju/index.php/ijhe/article/download/3885/3546. Diakses tanggal 28 September 2021.

Hamzah B. Uno. (2006). Perencanaan pembelajaran. Gorontalo: PT bumi aksara. dan Nina Lamatenggo(2016). Landasan Pendidikan. Gorontalo: Bumi Aksara.

I Dewa Gede Alit Rai Bawa, Sukadi, dan I Made Tegeh. (2014). Pengembangan bahan ajar IPS berorientasi IPS terpadu untuk siswa SMP kelas VII. (Online), pasca.undiksha.ac.id/e-journal/index.php/jurnal_tp/article/viewFile/1084/832.

Diakses tanggal 26 Februari 2016.

Konjo. (2011). Definisi bahan ajar. (online). http://jaririndu.blogspot.co.id/2011/09/definisibahan-ajar.html?m=1. Diakses tanggal 9 November 2021.

Mardati, Asih dan Hanum. (2018) Pengembangan Bahan Ajar Tematik Integratif Berbasis Local Wisdom Untuk Meningkatkan Interaksi Sosial Siswa Kelas IV SD. file://D:/tugas\%20JURNAL/jurnal\%20interaksi\%20sosial/garuda1082589.pdf.

Diakses tanggal 9 November 2021.

Nasution. (2011). Kajian pembelajaran IPS di sekolah. Surabaya: University Press.

Soerjono soekanto. (2012). Sosiologi suatu pengantar. Jakarta: PT Raja grafindo persada. Wina, Sanjaya. (2008). Perencanaan dan desain sistem pembelajaran Jakarta: Kencana prenada media grup. 
Inayatu Khoirul Magfiroh 